\title{
SLAUGYTOJŲ ŽINIOS APIE VAIKŲ SKAUSMO VERTINIMĄ
}

\author{
Silva Kostyliovienè ${ }^{1,2}$, Gintarẻ Žiobaitė ${ }^{1}$, Laura Urbonavičiūtè-Mikelkevičienė', \\ Alina Vaškelytė ${ }^{1,3}$, Dovilè Grinkevičiūtėe, \\ ${ }^{1}$ Kauno kolegijos Medicinos fakulteto Slaugos katedra, ${ }^{2}$ Lietuvos sveikatos mokslu universiteto \\ ligoninès Vaiku intensyviosios terapijos skyrius, ${ }^{3}$ Lietuvos sveikatos mokslu universiteto \\ Slaugos fakulteto Slaugos ir rūpybos katedra, ${ }^{4}$ Lietuvos sveikatos mokslu universiteto \\ Medicinos fakulteto Vaiku ligų klinika
}

Raktažodžiai: vaikų slaugytojai, slaugytojų žinios, vaikų skausmo vertinimas, skausmo vertinimo skalès.

\begin{abstract}
Santrauka
Skausmas yra vienas iš dažniausių simptomų, su kuriuo susiduria slaugytojai, slaugydami vaikus ligoninèse. Slaugytojams reikia turèti kompetencijos nuspręsti, kokị skausmo vertinimo instrumentą taikyti, ị kokius aspektus atsižvelgti skausmo vertinimo metu. Mokslinių tyrimų rezultatai rodo, kad slaugytojų žinios apie vaikų skausmo vertinimą yra nepakankamos. Šio tyrimo tikslas buvo išanalizuoti slaugytoju žinias apie vaikų skausmo vertinimą. Anketinė apklausa atlikta $2016 \mathrm{~m}$. vienoje iš didžiausių Lietuvos ligoninių vaikų chirurgijos (v. ch.) ir dviejuose vaiku ligu (v. 1.) skyriuose. Tyrime dalyvavo 61 slaugytojas. Rezultatai. Buvo nustatyta, kad didesnè dalis respondentų, dirbančių I v. 1. sk. (87,5 proc.) ir II v. 1. sk. (66,7 proc.), teigè, jog skausmo intensyvumą tiksliausia ịvardins pats pacientas, tačiau taip nurodè apie pusę $(54,5$ proc.) v. ch. sk. dirbančių respondentų $(\mathrm{p}=0,042)$. Dauguma $(70,0$ proc.) respondentų, dirbančių I v. 1. sk. nurode skausmo vertinimui naudojantys skales, tuo tarpu arti pusès (44,0 proc.) II v. 1 . sk. ir arti trečdalio (36,0 proc.) v. ch. sk. dirbančiu respondentų skausmo skales naudojo reikalui esant $(\mathrm{p}=0,003)$. Didesné dalis respondentų, dirbančių II v. 1. sk. (80,0 proc.) ir v. ch. sk. (63,6 proc.), naudojo žodinę skausmo skalę, tuo tarpu tik apie pusè $(45,8$ proc.) I v. 1. sk. dirbančių respondentų nurodè naudojantys šią skausmo skalę. Wong - Bakker veidelių išraiškos skalę skausmo vertinimui naudojo reikšmingai didesnè dalis respondentų, dirbančių I v. 1. sk. (70,8 proc.) ir v. ch. sk. (54,5 proc.), lyginant su II v. 1. sk. (13,3 proc.) dirbančiaisiais $(\mathrm{p}=0,003)$.
\end{abstract}

\section{Ivadas}

Vaikų skausmo vertinimas ir malšinimas - aktuali problema visame pasaulyje. Didžioji dalis vaikų yra patyrę skausmą, pradedant nuo kasdienybejje pasitaikančių nusibrozdinimų, susimušimų, sunkių traumų, o kartais ir dèl ūmios ar lètinès ligos. Nors pastaruoju metu teigiama, kad gydymo įstaigose vaikai yra nuskausminami, tačiau tyrimai atskleidè, kad vaikų skausmui vis dar skiriamas nepakankamas dèmesys ir jie kenčia ịvairaus intensyvumo skausmą [1-5]. Kanadoje atlikto tyrimo metu buvo nustatyta, kad 94,0 proc. hospitalizuotų vaikų patyre skausmą, 8,0 proc. - ūmų ir 62,0 proc. - patyre labai stiprų skausmą, susijusị su procedūromis [1].

Remiantis skirtingose užsienio šalyse atliktais tyrimais galima teigti, kad lètiniais skausmais skundžiasi nuo penktadalio iki pusès 8-16 metų vaikų [6-8]. Tarptautinio tyrimo metu (2014) dalyvavo 404206 paaugliai, kurių vidutinis amžius buvo 13,6 $(\mathrm{SN}=1,7)$ metų. Tyrimo dalyviai skundėsi ivairiais skausmais: galvos - 54,1 proc., skrandžio - 49,8 proc., nugaros $-37,0$ proc., o bent viena iš triju išvardintu skausmo rūšių skundèsi 74,4 proc. respondentų [8]. Statistinių duomenų apie lètinį skausmą patiriančių vaikų skaičių Lietuvoje nepavyko rasti. Tačiau, remiantis užsienio šalių vaikų lètinio skausmo statistikos duomenimis ir Lietuvos statistikos departamento duomenimis apie mūsų šalyje gyvenančių 8 - 17 metų amžiaus vaikų skaičiu, galima daryti prielaidą, kad kliniškai reikšmingą lètinį skausmą Lietuvoje patiria iki 14 tūkst. vaikų [9]. Buvo nustatytos sąsajos tarp skausmo ir dèl skausmo atsiradusių vaiko sveikatos problemų, tokių kaip: miego sutrikimai, nesugebèjimas užsiimti mégstama veikla, valgymo problemos, ugdymo ịstaigų nelankymas, negalejimas bendrauti su draugais ir kt. [7]. Skausmo sukeliamos vaiko sveikatos ir socialinès problemos parodo skausmo malšinimo svarbą, tačiau vaiko skausmas turi ir ekonominị poveikị $[6,10]$. Skausmo poveikis ekonomikai 
yra didžiulis, o bendros skausmo malšinimo sąnaudos sudaro iki 3,0 proc. BVP. Metinès skausmo gydymo išlaidos yra didesnès už širdies ligų ar vèžio gydymo išlaidas [6]. Jungtinèse Amerikos Valstijose buvo nustatytos išlaidos, skirtos malšinti paauglių lètini skausmą. Paaugliai buvo gydomi tarpdisciplininèse skausmo klinikose. Buvo tirta 149 paaugliu grupe, vienam dalyviui $2010 \mathrm{~m}$. numatomos vidinès ir vidutinès išlaidos sudare $11787 \mathrm{JAV}$ dolerių ir $6770 \mathrm{JAV}$ doleriu atitinkamai. Bendros išlaidos paaugliams, sergantiems vidutinio sunkumo ir sunkiu lètiniu skausmu, buvo ekstrapoliuotos iki 19,5 mlrd. JAV dolerių. Dèl lètinio paauglių skausmo kyla didele ekonominè našta šeimoms ir visuomenei [10].

Skausmas yra vienas iš dažniausių simptomų, su kuriuo susiduria slaugytojai, slaugydami vaikus ligoninèse [11]. Siekiant efektyviai malšinti skausmą, svarbu ji nustatyti ir ịvertinti. Egzistuoja daug mitų apie vaikų skausmą, tokių kaip „kūdikiai nejaučia skausmo“, „vaikai geriau toleruoja skausmą“, „vaiko elgesys visada parodo skausmo intensyvumą" ir kt., tačiau mokslininkai šiuos mitus paneigè [12]. Vaiko skausmo išraiška priklauso nuo vaiko amžiaus, pažinimo raidos ir sociokultūrinio konteksto, todẻl svarbu atkreipti ypatingą dèmesi i bet kokius vaiko elgesio pokyčius [13]. Vertinant paciento komforto būklę, ,auksinis" standartas yra paties paciento savo būklès įsivertinimas, tačiau vaikams dẻl mažo amžiaus, sutrikusios pažintinès funkcijos, sunkios ligos, dèl gydymui skirtų vaistų ar taikomų priemonių (pvz. intubacija ir dirbtinè plaučių ventiliacija) sunku, o kartais net neįmanoma tai atlikti [13 - 15]. Tokiais atvejais vaiko skausmą vertina sveikatos priežiūros specialistai, kurių ịvertinimas priklauso nuo jų turimų žinių apie patiriamą diskomfortą, skausmą, geriausius vaistus ir gydymą skausmui malšinti [14]. Slaugytojo žinios ir požiūris gali paveikti jo gebėjimą objektyviai vertinti vaikų skausmą ir ji valdyti [16]. Vertinant vaikų skausmą vaikams būtina naudoti skausmo vertinimo instrumentus - skales, kurios padeda tiksliau bei objektyviau ịvertinti tiriamojo skausmą ir išvengti vertintojo asmeninio poveikio. Lietuvoje sveikatos apsaugos ministro ịsakymu „Dèl būtinosios medicinos pagalbos ir būtinosios medicinos pagalbos paslaugų teikimo tvarkos bei masto patvirtinimo" naudojamos trys skausmo intensyvumo vertinimo skalès. İsakyme nurodoma, kad: „skausmo intensyvumo vertinimas taikomas pacientams nuo 3 metų, pasirinktinai naudojant ,veidukų“ ir/ar skaitmeninę, ir/ar žodinę skales. İvertintas skausmo intensyvumas pažymimas paciento medicinos dokumentuose ir yra laikomas pagrindu skirti atitinkamą skausmo malšinimo vaistą" [17]. Taip pat yra patvirtinta Naujagimių skausmo malšinimo" metodika, kurioje rekomenduojama naujagimio skausmą vertinti, naudojant PIPP (angl. Premature Infant Pain Profile) skausmo vertinimo skalę [18].
Lietuvos Respublikos sveikatos apsaugos ministro ịsakyme dẻl Lietuvos medicinos normos MN 28:2011 „Bendrosios praktikos slaugytojas. Teisès, pareigos, kompetencija ir atsakomybe" nurodyta, kad Bendrosios praktikos slaugytojas turi išmanyti skausmo valdymo principus; nustatyti skausmo intensyvumą, naudojant skausmo skales [19]. Slaugos specialistai privalo turèti kompetencijos nuspręsti, kokị skausmo instrumentą taikyti, į kokius aspektus atsižvelgti skausmo vertinimo metu bei stebèti skausmo gydymo efektyvumą.

Slaugytojoms, vertinant vaiko skausmą, svarbios teorinès žinios ir gebejjimas jas taikyti klinikinëje praktikoje. Tačiau atliktų tyrimų rezultatai atskleidè, kad sveikatos priežiūros specialistų žinios apie vaikų skausmą yra nepakankamos $[5,11]$. Australijoje atlikto tyrimo metu nustatyta, kad slaugytojai pooperacinị skausmą vertino rečiau nei buvo rekomenduojama, o vaiku pooperacinio skausmo vertinimas ir valdymas neatitiko mokslo įrodymais pagrịstų rekomendacijų [2]. Meksikoje 111 vaikų slaugytojų ir 300 medicinos universiteto slaugos studentų žinios apie vaikų skausmą buvo itin prastos [20]. Panašūs tyrimai atlikti kitose šalyse taip pat nustatè, kad slaugos specialistai stokojo žinių, susijusių su vaikų skausmo vertinimu; jie gebėjo atpažinti vaikų skausmą, tačiau nesinaudojo skausmo vertinimo instrumentais [21, 22].

Darbo tikslas: išanalizuoti slaugytojų žinias apie vaikų skausmo vertinimą.

\section{Tyrimo medžiaga ir metodai}

Tyrimas vyko $2016 \mathrm{~m}$. vienoje iš didžiausių Lietuvos ligoninių vaikų chirurgijos ir dviejuose vaikų ligų skyriuose. Kiekybiniam tyrimui atlikti buvo pasirinkta apklausa raštu. Tyrimo duomenims rinkti buvo naudojamas klausimynas, kuris parengtas remiantis mokslinès literatūros analize bei „Skausmo vertinimo žinių ir požiūrio klausimynu“ (angl. Knowledge and Attitudes Survey Regarding Pain) [23].

Dalyvauti tyrime buvo pakviesti visi 80 šiuose skyriuose dirbantys slaugytojai (vaikų chirurgijos sk. $n=22$; I vaikų ligų sk. $n=24$; II vaikų ligų sk. $n=15$ ). Išdalinta 80 klausimynų, iš kurių sugrižo 72, tinkami analizei buvo 61 . Atsako dažnis $-76,3$ proc.

Didžioji dalis respondentų buvo 40 - 59 metų amžiaus (77 proc.), išsimokslinimą ịiję medicinos mokyklose (59 proc.), turèjo didesnę nei $21 \mathrm{~m}$. klinikinio darbo patirti (63,9 proc.).

Rezultatų analizei ir duomenų pateikimui buvo naudota aprašomosios statistikos skaitinès charakteristikos: vidurkis, standartinis nuokrypis, pasiskirstymas dažniais pateikiamas procentine išraiška. Esant nenormaliam pasiskirstymui ir daugiau nei dviem grupėms buvo taikomas Kruskalio- Voliso (Kruskal- Wallis) testas. Esant normaliam pasiskirstymui tarp dviejų grupių, buvo taikomas T testas arba Stjudento (Student) testas, kai grupių buvo daugiau nei dvi - ANOVA 
testas. Kokybinių požymių statistinis ryšys buvo tiriamas susietų lentelių metodu. Remiantis lentelių duomenimis, apskaičiuota chi kvadrato $\left(\chi^{2}\right)$ reikšmė, laisvès laipsnių skaičius (lls), rezultatai laikyti statistiškai patikimais, kai statistinio reikšmingumo koeficientas $\mathrm{p}<0,05$.

Tyrimui atlikti buvo gautas Bioetikos centro pritarimas Nr. BEK - KK(B) - 07.

\section{Rezultatai}

Išanalizavus tyrimo rezultatus, buvo nustatyta, kad didesnè dalis respondentų, dirbančių I vaikų ligų skyriuje ( I v. 1. sk.) (87,5 proc.) ir II vaikų ligų skyriuje (II v. 1. sk.) $(66,7$ proc.), teige, jog skausmo intensyvumą tiksliausia ịvardins pats pacientas, tuo tarpu taip manė tik apie pusè (54,5 proc.) vaikų chirurgijos skyriuje (v. ch. sk.) dirbančių respondentų $\left(\chi^{2}=6,133 ; 11 s=2 ; p=0,042\right)$. Didesnè dalis respondentu, dirbančių v. ch. sk. nurodè, kad tiksliausia skausmo intensyvumą įvertins gydytojas $(63,6$ proc.) ir slaugytojas $(50,0$ proc.), tačiau taip teigè tik mažiau nei pusè respondentu, dirbančių II v. 1. sk. (gydytojas - 40,0 proc., slaugytojas 33,3 proc.) bei apie trečdalis respondentų, dirbančių I v. 1. sk. (gydytojas - 29,2 proc., slaugytojas - 33,3 proc.) $\left(\chi^{2}=5,674\right.$; $11 \mathrm{~s}=2 ; \mathrm{p}=0,051)$. Tik nedidelè dalis respondentų, dirbančių v. ch. sk. (9,1 proc.) ir II v. 1. sk. (13,3 proc.) teigè, kad paciento skausmą tiksliausia ịvardins paciento artimieji, bet taip nemanè nei vienas respondentas, dirbantis I v. 1. sk.

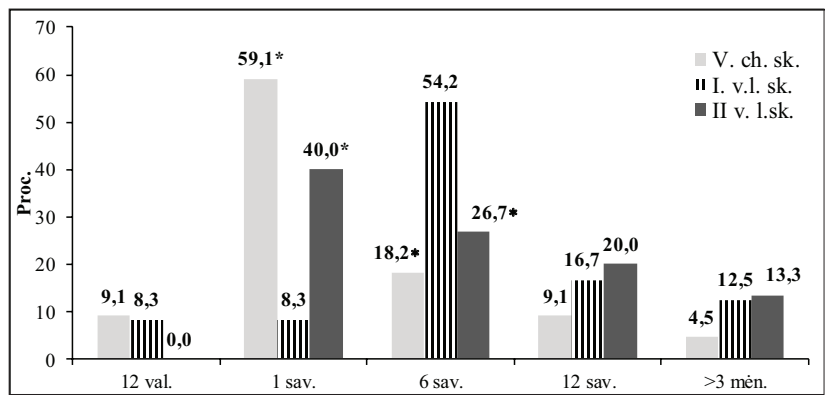

1 pav. Slaugytojų žinios apie lėtinio skausmo trukmę $p=0,029$, lyginant su I v. l. sk.

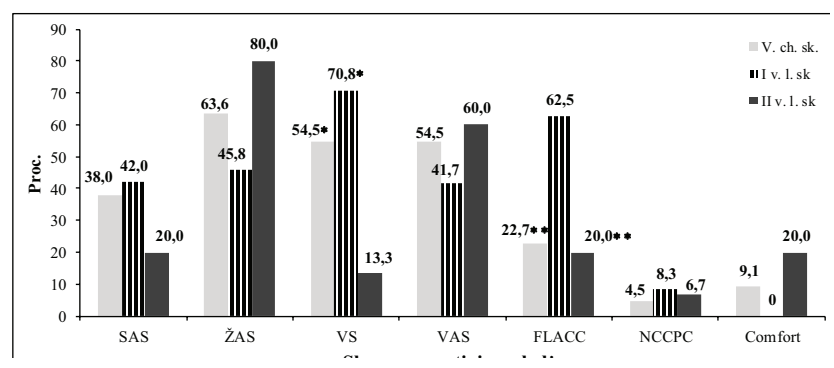

2 pav. Skausmo vertinimo skalių naudojimas

${ }^{*} p=0,029$, lyginant su II v. l. sk.; ${ }^{*} p=0,006$, lyginant su I v. l. sk
Reikšmingai didesnè dalis tyrimo dalyvių, dirbančių I v. 1. sk. (54,2 proc.), lyginant su dirbančiais II v. 1 . sk. (26,7 proc.) ir v. ch. sk. (18,2 proc.) nurodè, kad lètinio skausmo trukmè yra šešios savaitės. Tuo tarpu apie dešimtadalis I v. 1. sk. ( 12,5 proc.) ir II v. 1. sk. (13,2 proc.) bei maža dalis (4,5 proc.) v. ch. sk. dirbančių slaugytojų teigè, kad lètiniu skausmu vadinamas skausmas, kuris tęsiasi ilgiau nei tris mènesius. Reikšmingai didesnè dalis tyrimo dalyvių, dirbančių v. ch. sk. (59,1 proc.) ir II v. 1. sk. (40,0 proc.), lyginant su I v. 1. sk. (8,3 proc.) nurode, kad lètinio skausmo trukmè yra viena savaitè $\left(\chi^{2}=16,552 ; 1 l s=8 ; p=0,029\right)$ ( 1 pav.).

Domejomès, ar siekiant nustatyti skausmo intensyvumą slaugytojai naudoja skausmo vertinimo skales. Didžioji dalis (70,0 proc.) respondentų, dirbančių I v. 1. sk. nurodè naudojantys skausmo vertinimo skales, tuo tarpu arti pusès $(44,0$ proc.) II v. 1. sk. ir arti trečdalio (36,0 proc.) v. ch. sk. dirbančių respondentų skausmo skales naudoja reikalui esant $\left(\chi^{2}=16,926 ; 1 l s=6 ; p=0,003\right)$. Tik nedidelè dalis $(8,7$ proc. $)$ slaugytojų, dirbančių I v. 1. sk. nurodè, kad neturi skausmo vertinimo skalių, o nedidelè dalis slaugytojų, dirbančių II v. 1. sk., teigè, kad skausmo vertinimui nenaudoja vertinimo skalių. Nei vienas slaugytojas, dirbantis v. ch. sk., nenurodé, kad neturi skausmo vertinimo skalių ar jų nenaudoja.

Didesnè dalis tyrimo dalyvių II v. 1 . sk. (80,0 proc.) ir v. ch. sk. (63,6 proc.) naudojo žodinę skausmo vertinimo skalę

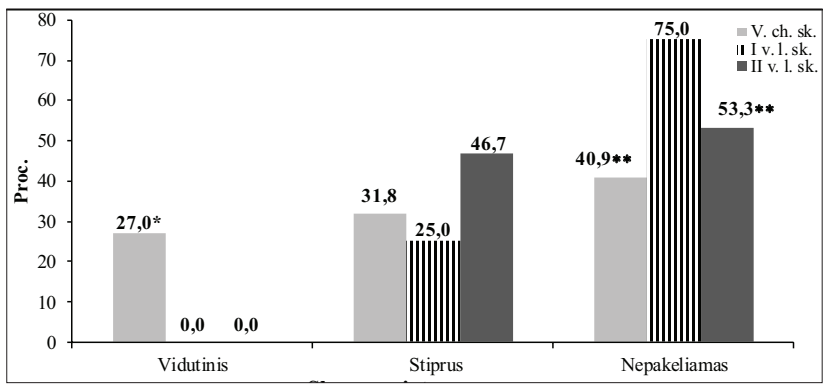

3 pav. Skausmo intensyvumo vertinimas pagal pateiktą situaciją $*_{p}=0,006$, lyginant su I v. l. sk. ir II v. l. sk.; **p=0,006, lyginant su I v. l. sk.

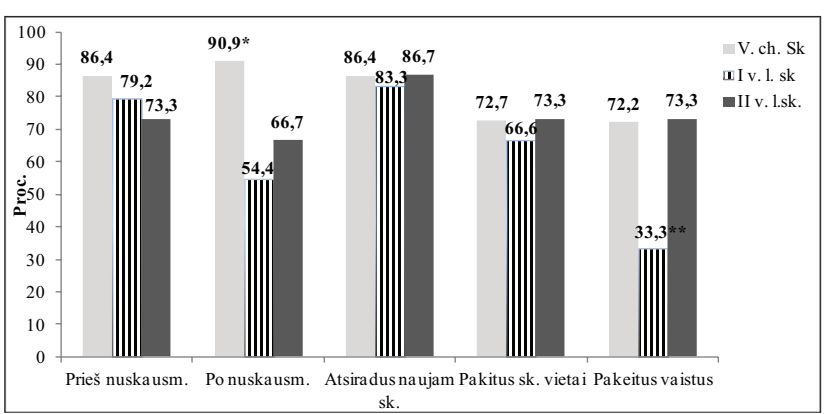

4 pav. Pakartotinis skausmo intensyvumo vertinimas

${ }^{*} p=0,023$, lyginant su I v. l. sk. ir II v. l. sk.; ** ${ }^{*}=0,009$, lyginant su v. ch. sk. ir I v. l. sk. 
(ŽAS), tuo tarpu tik arti pusès (45,8 proc.) I v. 1. sk. dirbančiu slaugytojų nurodė naudojantys šią skausmo vertinimo skalę.

Wong - Bakker veidelių išraiškos skalę (VS) skausmo vertinimui nurodè naudojantys reikšmingai didesnè dalis respondentų, dirbančių I v. 1. sk. (70,8 proc.) ir v. ch. sk. (54,5 proc.), lyginant su II v. 1. sk. (13,3 proc.) dirbančiais slaugytojais $\left(\chi^{2}=12,402 ; 11 s=2 ; p=0,003\right)$.

Reikšmingai didesnè dalis slaugytojų, dirbančių I v. 1. sk. (62,5 proc.), lyginant su dirbančiais II v. 1. sk. (20,0 proc.) ir v. ch. sk. (22,7 proc.) nurode, kad vaiko skausmui vertinti naudoja FLACC (angl. face, legs, activity, cry, consolability) skalę $\left(\chi^{2}=10,385 ; 11 s=2 ; p=0,006\right)$ ( 2 pav.).

Klausimyne buvo pateikta situacija, kuri atskleide slaugytojų žinias vertinant skausmą, remiantis skausmo klinikinès raiškos aspektais.

Situacija: vaikui 2 metai, paguldytas dèl II B laipsnio nudegimo. Slaugytojas, įejęs ị palatą mato, kad vaiko smakras nuolat virpa, lūpos stipriai sučiauptos, kojytès pritrauktos prie kūno, ịsitempęs, verkia ir kūkčioja, raminimas poveikio neturi. Mama pastebejo, kad vaikas nieko nevalgo.

Dèl duomenų išsibarstymo, analizuojant nurodytus skausmo vertinimo balus, sugrupavome: „silpnas skausmas“ atitinka 1, 2, 3 skausmo balus, „,vidutinis skausmas“ - 4, 5 balai, „stiprus skausmas“ $-6,7,8$ balai, „nepakeliamas skausmas" $-9,10$ balų.

Daugiau nei puse tyrimo dalyvių (57,4 proc.) šioje situacijoje vaiko skausmą ịvardijo kaip ,,nepakeliamą “, arti trečdalio (32,8 proc.) - ,, stiprų “, ir tik mažiau nei dešimtadalis (9,8 proc.) - ,, vidutinị “. Slaugytojų, dirbančių I v. 1. sk. aprašytoje klinikinèje situacijoje, vaiko skausmo vertinimo vidurkis balais buvo 8,9 balo, II v. 1 . sk. - 8,8, tuo tarpu v. ch. sk. dirbantys respondentai pateike statistiškai reikšmingai mažesnị skausmo vertinimo balo vidurki - 7,4 $\left(\chi^{2}=7,025\right.$; $11 \mathrm{~s}=2 ; \mathrm{p}=0,027)$.

Arti trečdalio (27,3 proc.) respondentų, dirbančių v. ch. sk., šioje situacijoje nurodè, kad vaiko skausmas yra ,, vidutinis ", tačiau taip nemanè nei vienas ( 0 proc.) slaugytojas I v. 1. sk. ir II v. 1. sk. $\left(\chi^{2}=14,350 ; 11 s=4 ; p=0,006\right)$. Reikšmingai didesnè dalis slaugytojų, dirbančių I v. 1. sk. (75,0 proc.), lyginant su dirbančiais II v. 1. sk. (53,3 proc.) ir v. ch. sk. (40,9 proc.), mane, kad vaiko skausmas pateiktoje situacijoje yra ,nepakeliamas" $\left(\chi^{2}=14,350 ; 11 s=4 ; p=0,006\right)(3$ pav. $)$

Analizuojant slaugytojų nuomonę bei požiūrị ị vaikų skausmą buvo pateikti teiginiai, su kuriais tyrimo dalyviai galëjo ,, sutikti“, „nei sutikti, nei nesutikti“, „,nesutikti““

Su teiginiu „vaikas, netekęs sąmonès, nejaučia skausmo intensyvumo“ ",sutiko “ reikšmingai didesnè dalis (83,3 proc.) I v. 1. sk. dirbančių slaugytojų, lyginant su II v. 1. sk. (33,3 proc.) ir v. ch. sk. (50,0 proc.) dirbančiaisiais $\left(\chi^{2}=11,091\right.$; $11 \mathrm{~s}=4$; $\mathrm{p}=0,025$ ).

Su teiginiu ,pacientas gali miegoti esant stipriam skausmui“", sutinku “ variantą pasirinko apie penktadalis $(20,0$ proc.) respondentų, dirbančių II v. 1. sk., tačiau ,, nesutinku “ variantą nurodė didžioji dalis respondentų, dirbančių I v. 1. sk. (87,5 proc.) ir v. ch. sk. $(95,5$ proc. $)\left(\chi^{2}=17,868 ; 11 s=8\right.$; $\mathrm{p}=0,013)$.

$\mathrm{Kad}$,apie skausmo intensyvumą galima spręsti iš vaiko veido išraiškos, kūno laikysenos" ", sutiko “visi (100 proc.) respondentų, dirbančių I v. 1. sk. ir v. ch. sk., tačiau penktadalis (20 proc.) dirbančiujų II v. 1. sk. pasirinko atsakymo variantą ,nei sutinku, nei nesutinku “ $\left(\chi^{2}=9,676 ; 11 s=2 ; p=0,012\right)$.

Daugiau nei pusė $(62,5$ proc.) respondentų, dirbančių I v.

1 lentelè. Slaugytojų požiūris į vaikų skausmą

${ }^{*} p<0,05$, lyginant su v. ch. sk. ir II v. l. sk. $\quad{ }^{* *} p<0,05$, lyginant su v. ch. sk. ir I v. l. sk.

\begin{tabular}{|c|c|c|c|c|c|c|c|c|c|c|}
\hline \multirow{2}{*}{ Nr. } & Respondentų požiūris & \multicolumn{3}{|c|}{ Sutinku } & \multicolumn{3}{|c|}{ Nei sutinku, nei nesutinku } & \multicolumn{3}{|c|}{ Nesutinku } \\
\hline & Teiginys & $\begin{array}{l}\text { V.ch. } \\
\text { sk. } \\
(\mathrm{n}=22) \\
\text { proc. }\end{array}$ & $\begin{array}{l}\text { I v. } 1 . \\
\text { sk. } \\
(\mathrm{n}=24) \\
\text { proc. }\end{array}$ & $\begin{array}{l}\text { II v. } 1 . \\
\text { sk. } \\
(\mathrm{n}=15) \\
\text { proc. }\end{array}$ & $\begin{array}{l}\text { V.ch. } \\
\text { sk. } \\
(\mathrm{n}=22) \\
\text { proc. }\end{array}$ & $\begin{array}{c}\text { I v. } 1 . \\
\text { sk. } \\
(\mathrm{n}=24) \\
\text { proc. }\end{array}$ & $\begin{array}{l}\text { II v. } 1 . \\
\text { sk. } \\
(\mathrm{n}=15) \\
\text { proc. }\end{array}$ & $\begin{array}{l}\text { V.ch. } \\
\text { sk. } \\
(\mathrm{n}=22) \\
\text { proc. }\end{array}$ & $\begin{array}{c}\text { I v. } 1 . \\
\text { sk. } \\
(\mathrm{n}=24) \\
\text { proc. }\end{array}$ & $\begin{array}{c}\text { II v. } 1 . \\
\text { sk. } \\
(\mathrm{n}=15) \\
\text { proc. }\end{array}$ \\
\hline 1. & $\begin{array}{l}\text { Pacientas ịprastai nejaučia } \\
\text { skausmo, kai yra netekęs są- } \\
\text { monès. }\end{array}$ & 50,0 & $83,3^{*}$ & 33,3 & 18,2 & 8,3 & 20,0 & 31,8 & $8,3^{*}$ & 46,7 \\
\hline 2. & $\begin{array}{l}\text { Pacientas gali miegoti, nepai- } \\
\text { sant stipraus skausmo. }\end{array}$ & 4,5 & 4,2 & $\begin{array}{c}20,0 \\
* *\end{array}$ & 0,0 & 3,3 & 13,3 & 95,5 & 87,5 & 67,5 \\
\hline 3. & $\begin{array}{l}\text { Apie skausmo intensyvumą ga- } \\
\text { lima spręsti iš veido išraiškos, } \\
\text { kūno padèties. }\end{array}$ & 100,0 & 100,0 & $\begin{array}{c}80,0 \\
* * \\
\end{array}$ & 0,0 & 0,0 & $\begin{array}{c}20,0 \\
* *\end{array}$ & 0,0 & 0,0 & 0,0 \\
\hline 4. & $\begin{array}{l}\text { Pacientas turètų patirti skausmo } \\
\text { sukeliamą diskomfortą prieš } \\
\text { gaudamas kitą nuskausmina- } \\
\text { mųjų vaistų dozę. }\end{array}$ & 50,0 & $29,2 *$ & 46,7 & 27,3 & $8,3^{*}$ & 26,7 & 22,7 & $62,5^{*}$ & 26,7 \\
\hline
\end{tabular}


1. sk. nesutiko su teiginiu ,pacientas turètu patirti skausmo sukeliamą diskomfortą prieš gaudamas kitą nuskausminamujų vaistų dozę", tuo tarpu arti pusès respondentų, dirbančių II v. 1. sk. ( 46,7 proc.) ir v. ch. sk. (50,0 proc.), sutiko su šiuo teiginiu " $\left(\chi^{2}=9,387 ; 11 s=4 ; p=0,05\right)$ ( 1 lentelè).

Analizuojant respondentų nurodytus skausmo vertinimo aspektus, nebuvo nustatyta statistiškai reikšmingų skirtumų tarp skyrių: didžioji dalis visų slaugytojų nurodé, kad vertindami vaiko skausmą atsižvelgia ị skausmo trukmę $(86,9$ proc.), lokalizaciją ( 88,5 proc.), intensyvumą ( 91,8 proc.) ir pobūdi ( 82,0 proc.). Prasidejus stipriam skausmui, daugiau nei trečdalis $(37,5$ proc.) respondentų, dirbančių I v. 1. sk., nurodè, kad skausmo intensyvumą vertintų kas 30 min., o skausmui atslūgus - kas 4 val.; tačiau tokiu laiko intervalu skausmo intensyvumą vertintų mažiau nei puse respondentų, dirbančių II v. 1. sk. (26,7 proc.) ir nedidelè dalis $(9,1$ proc.) v. ch. sk.

Didžioji dalis tyrime dalyvavusių respondentų teigè, kad pakartotinai vertintų skausmo intensyvumą prieš nuskausminimą ( 80,3 proc.), po nuskausminimo ( 70,5 proc.), kaskart atsiradus naujam skausmui (85,2 proc.), pakitus skausmo pobūdžiui ar vietai (68,9 proc.), ir tik apie pusè (57,4 proc.) - pakeitus nuskausminamuosius vaistus ar skausmą malšinančią procedūrą. Statistiškai reikšmingai didesnè dalis $(90,9$ proc.) v. ch. sk. dirbančių slaugytojų, lyginant su slaugytojais, dirbančiais I v. 1 . sk. (54,2 proc.) ir II v. 1 . sk. $(66,7$ proc.), nurodè, kad vertintų skausmą pakartotinai po skausmą malšinančių procedūrų $\left(\chi^{2}=7,589 ; 11 \mathrm{~s}=2 ; \mathrm{p}=0,023\right)$. Reikšmingai mažesnè dalis respondentų, dirbančių I v. 1. sk. (33,3 proc.) lyginant su dirbančiais II v. 1. sk. (73,3 proc.) ir v. ch. sk. (72,7 proc.) nurode, kad pakartotinai skausmą vertintų pakeitus analgetikus ar kitą skausmą malšinančią priemonę ar procedūrą $\left(\chi^{2}=9,355 ; 11 \mathrm{~s}=2 ; \mathrm{p}=0,009\right)$ ( 4 pav.).

Analizuojant duomenis apie vaikų su sutrikusia kognityvine funkcija ar nemokančių šnekamosios kalbos bei žemesnio intelekto vaikų skausmo vertinimą, neradome reikšmingų skirtumų analizuojant skirtinguose skyriuose dirbančių slaugytojų žinias. Beveik trečdalis tyrimo dalyvių manè, kad nereikalingas specialus, papildomas dèmesys vertinant skausmą vaikams, kuriems sutrikusi kognityvinè funkcija (27,9 proc.), emociškai labiliems vaikams (37,7 proc.), nemokantiems šnekamosios kalbos bei žemesnio intelekto (11,5 proc.).

\section{Diskusija}

Skausmo vertinimas yra labai svarbus norint pasiekti optimalų vaikų skausmo valdymą [5]. Nauji moksliniai tyrimai, rekomendacijos ir praktikos iniciatyvos pagerino naujagimių, vaikų ir paauglių skausmo valdymą, tačiau kokybiškam skausmo valdymui kliūtys išlieka. Rezultatai parodè, kad, nepaisant to, jog pastarajị dešimtmetị sutelkus dèmesi ị skausmo valdymo tobulinimą, skausmas vis dar yra ịprastas hospitalizuotiems vaikams [4]. Anglijoje (2013) buvo tirti veiksniai, trukdantys slaugytojams įvertinti skausmą, taip kaip jie noretų. Tyrimo metu paaiškejjo, kad veiksniai, susiję su sveikatos priežiūros darbuotojais yra: asmeniniai ịsitikinimai, išankstinès nuostatos, žinių stoka apie skausmo valdymą, skausmą malšinančius vaistus bei paciento kontroliuojamą analgeziją, baimè, kad bus perdozuoti vaistai, nepakankami personalo mokymai. Taip pat buvo nustatyti veiksniai, susiję su skausmą kenčiančiu vaiku ir jo tèvais: vaiko amžius; neatitikimai tarp slaugytojų siūlomų skausmo valdymo priemonių ir tėvų nuomonès apie jas; tėvų ar vaiko neinformavimas slaugytojų apie skausmą; vaiko skundimasis skausmu, nors jo elgesys nerodo skausmo; tèvų trukdymas ir atsisakymas skausmą malšinančių vaistų; vaikai nurodo padidintus skausmo vertinimo balus [24].

Mūsų atlikto tyrimo metu buvo nustatyti panašūs veiksniai, dèl kurių slaugytojai nepakankamai vertino vaikų skausmą. Pateiktoje situacijoje, kurioje dvejų metų vaikas (mažas vaiko amžius) jaučia nepakeliamą 9 balų (FLACC skalè) skausmą, tačiau iš aprašyto vaiko elgesio dalis tyrimo dalyvių atpažino ir ịvertino tik kaip vidutinị ir stiprų skausmą. Dalis respondentų neturejo aiškios nuomonès, kad apie skausmo intensyvumą galima spęsti iš vaiko veido išraiškos bei kūno laikysenos. Lietuvoje teisès aktais reglamentuotos ,veidukų“ ir/ar skaitmenine, ir/ar žodinè skalès, PIPP (angl. Premature Infant Pain Profile) skalė [17,18], tačiau neįvardyta kaip vertinti skausmą kūdikiui, esant sutrikusiai sąmonei ar esant sutrikusioms pažintinėms funkcijoms. Ligonineje, kurioje buvo vykdomas tyrimas, vaikų skausmui vertinti papildomai naudojama FLACC skalè. Tyrimais įrodyta, kad ši skalè puikiai koreliuoja su skaitmenine skale bei gali būti naudojama mažo amžiaus vaikams [14, 25].

Šiek tiek mažiau nei pusè ( 41,0 proc.) mūsų tyrime dalyvavusių slaugytojų mané, kad vaikas turètų patirti skausmo sukeliamą diskomfortą prieš gaudamas kitą nuskausminamujjų vaistų dozę. Rekomendacijose teigiama, kad geriausia skausmą įvertina pats vaikas, jei vaikas to negali, i jo skausmo vertinimą gali būti įtraukti artimieji [13 - 15]. Atlikti tyrimai ịrodè, kad slaugytojai ir nepriklausomi stebėtojai nurodo mažesnį skausmo balą nei tèvai ar vaikai, todèl gali būti skiriamas netinkamas skausmo gydymas [15]. Izraelyje (2015) atlikto tyrimo metu nustatyta, jog arti trečdalio (34,0 proc.) slaugytojų teigé, kad vaiko skausmą gali vertinti tèvai [11]. Mūsų tyrimo metu tik nedidelè dalis (6,6 proc.) slaugytojų mané, kad vaiko artimieji gali tiksliausiai ịvertinti vaiko skausmą, o daugiau nei trečdalis tiriamujų nurodè, kad tiksliausiai tai ịvertinti gali gydytojas (44,3 proc.) ar 
slaugytojas (39,3 proc.).

Tyrimų rezultatai rodo, kad per mažai dėmesio skiriama sveikatos priežiūros specialistams, kuriems nepakanka žinių apie vaikų skausmo vertinimą ir gydymą, dèl to didelè dalis jų negeba atpažinti skausmo, netaiko skausmo vertinimo skalių $[5,11]$. Jau minèto (2015) tyrimo metu dalyvavo 82 vaikų slaugytojai, kurių dauguma ( 90,0 proc.) buvo susipažinę su skausmo skalèmis, bet didžioji dalis $(86,0$ proc $)$ vaiko skausmą vertino atsižvelgdami ị savo bendrą įspūdị apie vaiko skausmą [11]. Mūsų atlikto tyrimo metu kai kuriuose skyriuose daugiau nei pusė $(54,1$ proc.) slaugytojų nurodè naudojantys skausmo vertinimo skales. Panjganj D. ir Bevan A. (2016) nustate, kad kartais slaugytojai skausmo vertinimo skales naudoja netinkamai, o vaikų elgesio pokyčius supranta neteisingai [5].

Didelį susirūpinimą kelia vis dar egzistuojantis atotrūkis tarp rekomenduojamų vaikų skausmo vertinimo gairių ir klinikinès praktikos, kai slaugytojai, vertindami skausmą, remiasi kuriuo nors vienu veiksniu ar subjektyvia savo nuomone, neatsižvelgdami ị skausmo išgyvenimo kompleksiškumą [11]. Daugelyje šalių atliktų tyrimų rezultatai parodè, kad slaugytojams vis dar trūksta žinių apie vaikų skausmo vertinimą ir valdymą $[2,5,11,15,21]$.

Mūsų tyrimo rezultatai taip pat atskleidè, kad slaugytojams nepakanka žinių apie vaikų skausmo vertinimą: dalis slaugytojų nenaudoja skausmo vertinimo skalių, nežino lètinio skausmo trukmès. Lètinis neonkologinis skausmas nusakomas kaip skausmas, kuris tęsiasi ilgiau kaip 3 mèn. arba jo trukmè yra ilgesnè, negu numatomas ligos, dèl kurios kilo skausmas, išgydymas, audinio, dèl kurio kilo skausmas, sugijimas $[13,26]$. Pateiktoje klinikineje situacijoje tyrimo dalyviai neatpažino „nepakeliamo“ vaiko skausmo, didelè dalis teigé, kad geriausia vaiko skausmą ịvertintų sveikatos priežiūros personalo nariai. Šis tyrimas atskleidè probleminius vaikų skausmo aspektus ir įrodé, kad Lietuvoje reikia įdiegti standartizuotas vaikų skausmo vertinimo ir valdymo rekomendacijas, parengti vaikų skausmo vertinimo algoritmus bei mokymo programą slaugytojams.

\section{Išvados}

1. Didžioji dalis slaugytojų žinojo, kad tiksliausiai skausmą gali vertinti pacientas, teisingai nurodè svarbius skausmo aspektus ir skausmo vertinimo intervalus, skausmo vertinimui naudojo skaitmeninę ar žodinę skausmo vertinimo skales. Didesnè dalis tyrimo dalyvių skirtų specialų, papildomą dèmesị vertinant vaikų skausmą, kuriems sutrikusi kognityvinè funkcija, emociškai labiliems vaikams, nemokantiems šnekamosios kalbos bei žemesnio intelekto.

2. Didesnè dalis tyrimo dalyvių nežinojo lètinio skausmo trukmès, jog vaikas neturètų patirti skausmo sukeliamą diskomfortą prieš gaudamas kitą nuskausminamujų vaistų dozę ir kad esantis be sąmonès vaikas taip pat jaučia skausmo intensyvumą, o vaiko artimieji gali tiksliai įvertinti vaiko skausmą.

\section{Literatūra}

1. Birnie KA, Chambers CT, Fernandez CV, Forgeron PA, Latimer MA, McGrath PJ, Cummings EA, Finley AG. Hospitalized children continue to report undertreated and preventable pain. Pain Research and Management 2014; 19(4): 198-204. Prieiga per internetą: http://europepmc.org/articles/pmc4158935.

2. Shrestha-Ranjit JM, Manias E. Pain assessment and management practices in children following surgery of the lower limb. Journal of Clinical Nursing 2010; 19(1-2): 118-128. https://doi.org/10.1111/j.1365-2702.2009.03068.x

3. Lee GY, Yamada J, Kyololo O, Shorkey A, Stevens B. Pediatric clinical practice guidelines for acute procedural pain: a systematic review. Pediatrics 2014; 133(3):500-15.

https://doi.org/10.1542/peds.2013-2744

4. Kozlowski LJ, Kost-Byerly S, Colantuoni E, Thompson C B, Vasquenza KJ, Rothman SK. et al. Pain prevalence, intensity, assessment and management in a hospitalized pediatric population. Pain Management Nursing 2014;15(1), 22-35.

https://doi.org/10.1016/j.pmn.2012.04.003

5. Panjganj D, Bevan A. Children's nurses' post-operative pain assessment practices: Donya Panjganj and Ann Bevan's literature review finds that nurses' approaches to post-operative pain assessment for children may be contributing to inadequate pain management. Nursing Children and Young People 2016; (28)5: 29-33.

https://doi.org/10.7748/ncyp.28.5.29.s23

6. Henschke N, Steven JK, Chris GM. The epidemiology and economic consequences of pain. Mayo Clin Proc 2015; 90(1):139-47.

https://doi.org/10.1016/j.mayocp.2014.09.010

7. Roth-Isigkeit A, Thyen U, Sto"ven H, Schwarzenberger J, Schmucker P. Pain among children and adolescents: restrictions in daily living and triggering factors. Pediatrics 2005; 115(2), 152-162.

https://doi.org/10.1542/peds.2004-0682

8. Swain MS, Henschke N, Kamper SJ, Gobina I, Ottová-Jordan $\mathrm{V}$, Maher CG. An international survey of pain in adolescents. BMC Public Health 2014; 14(1): 447.

https://doi.org/10.1186/1471-2458-14-447

9. Ališauskaitė I., Ruževičienė D., Raistenskis J., Svetikienė V., Žilinskaitè V. Lètinis vaikų skausmas biopsichosocialiniu požiūriu: samprata, ịvertinimo ir gydymo strategija. Medicinos teorija ir praktika, 2015; 21 (3.1): 298-306.

10. Groenewald CB, Essner BS, Wright D, Fesinmeyer MD, Palermo TM. The economic costs of chronic pain among a cohort of treatment-seeking adolescents in the United States. The Journal 
of Pain 2014; 15(9): 925-933.

https://doi.org/10.1016/j.jpain.2014.06.002

11. Zisk-Rony RY, Lev J, Haviv H. Nurses' report of in-hospital pediatric pain assessment: examining challenges and perspectives. Pain management nursing: official journal of the American Society of Pain Management Nurses 2015; 16(2), 112-120.

12. O'Keeffe N. Pain: rituals and myths. World of Irish Nursing 2002; 10(1): 22-24. Prieiga per internetą: https://www.inmo. ie/Article/PrintArticle/2476.

13. WHO Guidelines on the Pharmacological Treatment of Persisting Pain in Children with Medical Illnesses, 2012. Prieiga per internetą: http://apps.who.int/iris/bitstream/10665/44540/1/9789241548120_Guidelines.pdf .

14. Harris J, Harris J, Ramelet AS, van Dijk M., Pokorna P, Wielenga J, Tume L, Tibboel D, Ista E. Clinical recommendations for pain, sedation, withdrawal and delirium assessment in critically ill infants and children: an ESPNIC position statement for healthcare professionals. Intensive Care Medicine 2016; (42)6: 972-986.

https://doi.org/10.1007/s00134-016-4344-1

15. Khin Hla T, Hegarty M, Russell P, Drake-Brockman TF, Ramgolam A, Ungern-Sternberg BS. Perception of pediatric pain: a comparison of postoperative pain assessments between child, parent, nurse, and independent observer. Pediatric Anesthesia 2014; 24(11), 1127-1131.

https://doi.org/10.1111/pan.12484

16. Stanley M, Pollard D. Relationship between knowledge, attitudes, and self-efficacy of nurses in the management of pediatric pain. Pediatric Nursing 2013; 39(4):165-171. Prieiga per internetą: http://www.pediatricnursing.net/ce/2015/ article3904165171.pdf.

17. Lietuvos Respublikos Sveikatos Apsaugos Ministro įsakymas. "Dèl Būtinosios medicinos pagalbos ir būtinosios medicinos pagalbos paslaugų teikimo tvarkos bei masto patvirtinimo". $2004 \mathrm{~m}$. balandžio 8 d. Nr. V-208.Vilnius, 2004. Valstybès žinios, 2004-04-16, Nr. 55-1915.

18. Aldauskienė I. Ir kt. Naujagimių skausmo malšinimas. Metodika, 2014. Prieiga per internetą: https://sam.lrv.lt/uploads/sam/ documents/files/Veiklos_sritys/Programos_ir_projektai/Sveicarijos_parama/Neonatologines_metodikos/Naujagimiu $\% 20$ skausmo\%20malsinimas.pdf.

19. Lietuvos Respublikos sveikatos apsaugos ministro ịsakymas "Dèl Lietuvos Medicinos Normos MN 28:2011 "Bendrosios praktikos slaugytojas. Teisès, pareigos, kompetencija ir atsakomybė" patvirtinimo. 2011 m. birželio 8 d. Nr. V-591, Vilnius. Valstybès žinios, 2011-06-14, Nr. 72-3490.

20. Ortiz MI, Ponce-Monter HA, Rangel-Flores E, Castro-Gamez B, Romero-Quezada LC, O'Brien JP, Romo-Hernánde G, Escamilla-Acosta MA.Nurses' and nursing students' knowledge and attitudes regarding pediatric pain. Nurs Res Pract 2015; 2015: 210860.

https://doi.org/10.1155/2015/210860

21. Mathew PJ, Mathew JL, Singhi S. Knowledge, attitude and practice of pediatric critical care nurses towards pain: Survey in a developing country setting. Journal of Postgraduate Medicine 2011; (57)3: 196.

https://doi.org/10.4103/0022-3859.85203

22. Silva MS, Pinto MA, Gomes LMX, Barbosa TLDA. Pain in hospitalized children: nursing team perception. Revista Dor 2011; (12)4: 314-320. Prieiga per internetą: http://www.scielo. br/pdf/rdor/v12n4/en_a06v12n4.pdf.

23. Ferrell BR, McCaffery M. Knowledge and attitudes survey regarding pain 2014. Prieiga per internetą: http://prc.coh.org/ Knowldege\%20\%20\&\%20Attitude\%20Survey\%207-14\%20 (1).pdf.

24. Twycross A. Nurses' views about the barriers and facilitators to effective management of pediatric pain. Pain Management Nursing 2013; (14)4: e164-e172.

https://doi.org/10.1016/j.pmn.2011.10.007

25. Ray D, Ghosh S, Swaika S, Gupta R, Mondal A, Sengupta S. Combination of self-report method and observational method in assessment of postoperative pain severity in 2 to 7 years of age group: A cross-sectional analytical study. Indian Journal of Pain 2015; 29(2), 86.

https://doi.org/10.4103/0970-5333.155176

26. Ščiupokas A. Lètinio neonkologinio skausmo gydymas opioidiniais analgetikais. Skausmo medicina, 2006; 1(14):45.

\section{NURSES‘ KNOWLEDGE ABOUT ASSESSING PAIN IN CHILDREN}

S. Kostyliovienė, G. Žiobaitè, L. Urbonavičiūtè-

Mikelkevičienė, A. Vaškelytė, D. Grinkevičiūtė

Key words: pediatric nurses, nurses' knowledge, pain assessment in children, pediatric pain scales.

Summary

Pain is one of the most frequent symptoms the nurses face with while taking care of hospitalized children. The nurses have to be competent in choosing appropriate pain assessment tool or taking into account various aspects while assessing pain. Studies show, that nurses' knowledge about pain assessment in children are insufficient. Aim of this research was to analyze nurses' knowledge about pain assessment in children.

The method used was a descriptive survey. Nurses from pediatric surgical unit ant two pediatric units in one of the largest hospital in Lithuania participated in the study. The questionnaire was filled by 61 nurse.

Results. Majority of the respondents from $1^{\text {st }}$ pediatric unit $(87.5 \%)$ and $2^{\text {nd }}$ pediatric unit $(66.7 \%)$ thought that the most effective pain assessment is by the patient himself, but only about half of the respondents from pediatric surgical unit $(54,5 \%)$ had the same opinion. Majority $(70 \%)$ of respondents from $1^{\text {st }}$ pediatric unit are using pediatric pain scales for assessing pain, meanwhile about half $(44.0 \%)$ of the nurses from $2^{\text {nd }}$ pediatric unit and one third $(36.0 \%)$ from pediatric surgical unit used pain scales if necessary. Major part of the respondents from $2^{\text {nd }}$ pediatric unit $(80.0 \%)$ and pediatric surgical unit (63.6\%) used Numeric Rating Scale (or verbal), and only almost half of the nurses from $1^{\text {st }}$ pediatric unit 


\section{6}

$(45.8 \%)$ stated, that they use this scale. Wong - Bakker Faces Pain Scale was used by significantly bigger part of the nurses from $1^{\text {st }}$ pediatric unit (70.8\%) and pediatric surgical unit (54.5\%), comparing with $2^{\text {nd }}$ pediatric unit nurses $(13.3 \%)$.

Conclusions. 1. The majority of the nurses knew that the most effective pain assessment is by the patient himself, correctly pointed the most important aspects of pain, pain assessing intervals and used numeric or verbal pain assessing scale. The bigger part of the respondents would pay special attention assessing pain in children who have cognitive dysfunction, emotional lability, lo- wer IQ or don't know the language. 2. The bigger part of the respondents didn't know the duration of chronic pain, about the fact, that the child should not suffer from pain before the next dose of pain killers, that unconscious child also suffers from pain and the relatives can precisely evaluate pain intensity.

Correspondence to: silva.kostylioviene@go.kauko.lt

Gauta 2017-09-14 